\title{
The Liver of Prometheus (Prometheova játra)
}

\author{
Author: Jiři Kolář
}

First Published: 1979 (in samizdat), 1985 (exile publishing house in Toronto)

Translations: French (Le Foie de Prométhée. Journal 1950, 1985); Italian (Il fegato di Prometeo, 2009); German (Die Leber des Prometheus, 2019).

Music Adaptation: Prométheova játra (The Liver of Prometheus), symphonic poem inspired by Jiří Kolář, composer Jan Kučera, 2002.

About the Author: Jiři Kolář (1914-2002) was a graphic artist, poet, essayist and translator. He started his creative career in the early 1930s with surrealist poems. Kolár belonged to the left-oriented artistic and literary Group 42. Due to the Communist coup in 1948, he could not publish from 1949 to 1957. He spent eight months in prison in 1953 for the "subversive" manuscript of The Liver of Prometheus. At the end of 1950s, he gradually turned away from writing and concentrated on artistic work. His visual poetry and collages won him world fame with dozens of exhibitions. His entire work was exhibited in the Guggenheim Museum in New York in 1975 and in other major Western museums of modern art. In the 1970s and 1980s, again, he could not publish except in samizdat or exile. In 1977, Kolár̆ signed the human rights manifesto Charter 77 and while on a scholarship to West Berlin, the Czechoslovak government decided to force him to emigrate with no permission to return to Czechoslovakia. He lived in Paris from 1980 to 1989, and afterwards, he regularly travelled between Paris and Prague.

Further Important Publications: Ódy a variace (Odes and Variations, 1946; poems); Dny $v$ roce (Days in a Year, 1948; poems); Roky $v$ dnech (1949, all copies of the book were confiscated, samizdat 1975, Years in Days; diaries and poems); Očitý svědek (written 1949, samizdat 1975, Munich 1983, Eyewitness; diaries and poems); Náhodný svědek (1964, Accidental Witness; anthology of poems); Básně ticha (1965, Poems of Silence, visual poems); Mor v Athénách (1965, $\rightarrow$ Plague in Athens; play); Nâvod k upotřebení (1969, A User's Manual; poems).

\section{Content and Interpretation}

The Liver of Prometheus, written in 1950, is a collection of poems, diary entries, reflections, aphorisms and quotes. Deeply experimental and fragmentary in its nature, it assumes the form of a literary collage (a technique using various sources and forms which are subsequently assembled into a new whole) that characterises Kolářs work in general. The collection is divided into three parts: A Real Occurrence (Skutečná událost), A Cheerful Cemetery (Jásající hřbitov) and Everyday Comedy (Každodenní

Ә Open Access. (C) 2021 Kateřina Voborská, published by De Gruyter. (cc) BY-NC-ND This work is licensed under a Creative Commons Attribution-NonCommercial-NoDerivatives 4.0 License. https://doi.org/10.1515/9783110671056-063 
komedie). The first and third part are all tied together under the subtitle The Genor Clan, which signals a certain generational development, in the case of Kolár̆, a decline or degradation stemming from the totalitarian regime.

This article will primarily discuss the first part of the collection that explicitly deals with the topic of the Shoah. The text opens with a quote from Ladislav Klima Czech nonconformist writer and philosopher, and continues as a variation on Klima's story A Real Occurrence that Happened in Postmortalia (1932) and a deconstruction of Zofia Nałkowska's short-story By the Railway Track $\rightarrow$ Medallions (whose translation into Czech is reprinted as a part of The Liver of Prometheus). Kolář merges these two writings through a process he describes in the afterword (samobáseň; Kolář, 2016, p. 32). Accordingly, it is an intertextual poem constructed as a literary prollage where multiple artworks are being reproduced in parts which are reassembled in a new artwork as intermingling and complementing each other. It demonstrates a multiplicity of perspectives and a sense of contingency. In the fashion of T. S. Eliot's The Waste Land, the poem echoes those written before, its voice recalling the voices of the past, signifying the entanglement of the past with the present that inevitably shapes our perception of everyday reality. Consequently, it is possible to identify this entanglement as a ghostly presence; an invisible remnant of the past affecting the present.

In the poem, the lyrical subject finds Genor in a pub, at the table with the ghost of his wife. The invisible acquires not only a name - Mařenka (nickname for Mary in Czech), but also a voice and a background story, becoming almost tangible since Genor acts as if her body is present, thereby acknowledging the existence of the absent. The invisible woman overlaps with Nałkowska's Jewess, who attempts to escape from the train while it is on the way to the concentration camp, but is shot in her leg. She is therefore forced to stay by the railway track and soon, she is surrounded by a group of onlookers from the Polish village. Because of the strict rules and prohibitions considering the Jews, the onlookers are afraid to offer assistance with her injury. There is only one man who stays by her side, provides her with vodka and cigarettes and finally shoots her to save her from suffering. An opposition arises here between the inability to act due to physical obstacles and due to the ones that are mental. The Jewess being completely unable to move is linked to animalistic imagery and accordingly reflects the conflict of the human with the dehumanised and inhuman that is played out in the story.

Simulating a conversation in a pub, Kolář’s verses present Genor's story which at first comes across rather as discontinuous bits told by a drunken madman. These seemingly nonsensical utterances in fact contain quotes from Nałkowska's text that is being dissected within the poem. Kolář provides the reader with three different versions of the poem, editing his lines, twisting and adding information. Therefore, the verses are gradually expanding, simultaneously becoming more coherent. What initially appears to be unstable in regard to the lack of meaning, gradually grows rather comprehensible, albeit still intertwined with moments of silence and ellipses. 
It is possible to interpret Kolářrs effort to undermine meaning as mimicking the inability to understand the Holocaust in its totality and its significance for society. This is already indicated in the opening of the first part presenting Klima's quote, "But what about that horrendous comedy? What was the reason for all of that? What does it all mean?” (Kolář, 2016, p. 7).

In the other two parts of his collection, Kolář mainly focuses on the oppressive Communist regime, alluding to the Shoah and its aftermath as a marking point of enormous cruelty and brutality that can be done at the hands of humankind. Here, Kolár expresses personal responsibility for the damage done to the victims and the need to act against the evils of the totalitarian regime.

\section{Main Topics and Problems}

The text is inseparably intertwined with the notion of a haunting past. The Holocaust spectre originates in the frequent references to that which is absent, stimulating the form of an absent presence. The disastrous consequences of the Holocaust are deeply embedded in human history and collective memory. Memory is therefore crucial for the collection as a tool that shapes our consciousness, transfers experience and preserves images of the past.

Nonetheless, is it important to note that in regard to the trauma caused by the past events, these images are transformed, filtered and edited to be bearable and comprehensible for the witness and for the receiver. This occurrence is also reflected in the fragmentary, disrupted form of Kolář's writings.

Restricted by the Communist regime, Kolár is constantly being reminded of the Shoah, reliving the trauma, remembering the victims and their suffering. Unable to think separately of the past and the present, Kolář interprets the events of World War II as showing the limits of human atrocity and evil, in fact showing that the limits are much greater than anyone can imagine. One of the main thoughts of the work thus can be summarised by Kolář's statement that, "any form of totalitarianism always leads towards inhumanity, always leads towards beastly behaviour” (p. 54). Kolář defines his existence as conditioned by totalitarianism that requires the citizens to identify with its ideology, forces them to repress their individuality, dehumanises them and oppresses them through various forms of terror such as censorship, surveillance or physical violence.

At the same time, The Liver of Prometheus represents Kolářs's way to confess and to repent as he contemplates the meaning of good and evil and describes his guilt surrounding his passivity in the past in relation to the victims. In a strong contrast to this determination stands the author's anxiety bordering on hopelessness, which can be detected especially in the passages examining the immoral behaviour and brutal acts of men. Comparably to Nałkowska's Jewess, Kolář ultimately finds himself and indeed the entire society in a position in which the will to act is repressed, paralysed by fear and forcibly transformed into passivity. 


\section{Cited Works}

Eliot, T. S. (2004). The Waste Land. New York: W. W. Norton \& Co. Klíma, L. (2011). A Real Occurrence that Happened in Postmortalia. In: L. Klíma, Glorious Nemesis. Prague: Twisted Spoon Press. Kolář, J. (2016). Prometheova játra. Trilogie, eds. J. Říha, P. Šrámek. Brno: Host. Nałkowska, Z. (2000). Medallions. Evanston: Northwestern University Press.

\section{Further References}

Bažant J., Bažantová, N. (2010). Prometheus’ Liver, Jiří Kolář. In: The Czech Reader: History, Culture, Politics, eds. J. Bažant, N. Bažantová, F. Starn. Durham: Duke University Press, pp. 353-354. Bezdíček V. (2007). Beyond the Apocalypse: Czech Verse on the End of the Second World War. Central Europe, 5(2), pp. 159-187. Suk, M. (2013). „Jsem člověk, který se těžko podvoluje“. Proces s Jiřím Kolářem v roce 1953. Česká literatura, 61(4), pp. 547-569. Holý, J. (2008). Writers under Siege: Czech Literature since 1945. Brighton: Sussex Academic Press, 2008, pp. 30-31 and 251. Lingwood J. (1990). Jiri Kolar: The End of Words - Selected Works 1948-1970. London: Institute of Contemporary Arts. Říha, J., Šrámek, P. (2016). Komentář. In: J. Kolář, Prometheova játra. Brno: Host, pp. 395-530. 